\title{
Teachers as Self-Directed Learning Guides
}

\section{Louise Ohashi}

Meiji University

\section{Nicholas Delgrego}

Tsuru Bunka University

\section{James Underwood}

Gakushuin University

\section{Mayumi Abe \\ Waseda University}

\section{Reference Data}

Ohashi, L., Delgrego, N., Underwood, J., \& Abe, M. (2021). Teachers as self-directed learning guides. In P. Clements, R. Derrah, \& P. Ferguson (Eds.), Communities of teachers \& learners. JALT. https:// doi.org/10.37546/JALTPCP2020-32

This article reports on research and teaching methods related to self-directed learning (SDL) that were presented by four SDL teachers in a forum at JALT2020. There is growing interest in the role teachers and institutions can play in fostering learner autonomy (Blidi, 2017; Lai, 2017; Murray, 2014; Ohashi, 2018, 2019). This article addresses the need for greater transparency in the practical aspects of aiding students to take charge of their learning within and beyond classrooms. It shows different ways each author approached the same SDL course that they taught at a university in Tokyo, by introducing language learning histories, future self exploration, planning-action-reflection cycles, negotiated goal contracts, learning logs, and asynchronous peer interaction. Through sharing their experiences, insights, and research outcomes, the authors hope to contribute knowledge of practical ways in which SDL can be approached by teachers and institutions.

本稿では、自己主導型学習 (self-directed learning、以下SDL) の授業を担当する4名の教師がJALT2020のフォーラムで発表 したSDLに関する研究と教授方法を報告する。学習者の自律性の育成において、教師や教育機関が果たせる役割への関心が 高まつている (Blidi, 2017; Lai, 2017; Murray, 2014; Ohashi, 2018, 2019)。本稿は、学生が授業内外で学習に主体的に取り組む ための実践的な支援方法の透明性を高める二ーズに応える。著者らは東京の同じ大学で同一科目SDLを担当し、それぞれが 言語学習ヒストリー、将来の自分探し、計画一実行一省察サイクル、交渉した目標の契約、学習ログ、非同期ピア・インタラクシ ヨンという異なるアプローチを実践した。本稿ではこれらの経験、洞察、研究成果を共有し、教師や教育機関によるSDL支援方 法に関する知見を提供する。

7 here is growing interest in the role that language teachers and institutions can 1 play in fostering learner autonomy within formal language education (Blidi, 2017; Lai, 2017; Murray, 2014; Ohashi, 2018, 2019). Interest in autonomy in language learning contexts stretches back to the 1980's, with Holec (1981) defining autonomy as "the ability to take charge of one's own learning" (p. 3). A decade later, Little expanded upon this, defining autonomy as the capacity learners have "for detachment, critical reflection, decision-making, and independent action" (1991, p. 4). He argued against the assumption that teachers must step back for this to occur, rejecting the contention "that any intervention on the part of the teacher may destroy whatever autonomy the learners have managed to attain" (Little, 1991, p. 5). On the contrary, there is support for the notion that teachers can play an important role in fostering learner autonomy. As noted by Murphey and Jacobs, "Being autonomous does not necessarily mean learning in isolation, but rather having the ability to metacognitively and critically make decisions as to the means one uses to learn and develop" (2000, p. 228). More recently, this sentiment has continued to be expounded, with initial reliance upon teachers repositioned as an opportunity "that should be properly exploited to help in the development of learner autonomy" (Blidi, 2017, p. xxix).

This article offers a practical perspective on how four teachers at a university in Tokyo sought to help their learners to effectively manage their own learning. The initial step 
was taken by the university by embedding the subjects Self-Directed Learning $\mathrm{I}$ and Il into the core curriculum in the Faculty of International Social Sciences to facilitate autonomous language learning. In this faculty, all students are required to enroll in these credit-bearing courses in their first year of university and passing them is a requirement for graduation. Teachers in the department meet regularly to discuss the syllabuses and consider best practices for meeting course aims. The authors of this article have worked there together for several years and extensively discussed the activities they implement to practically address the aims of their courses. They shared that knowledge more widely through their forum at JALT2020 (a recording is available at https://www.youtube.com/ watch?v=KFRiHlys $2 u 8$ ) and hope to extend their reach further through this article.

Two Japan-based journals, SiSAL Journal (Studies in Self-Access Learning, https:// sisaljournal.org/) and JASAL Journal (Japan Association for Self-Access Learning, https:// jasalorg.com/jasal-journal/) have contributed much to the field of learner autonomy in recent years. Many articles in these journals consider the roles of self-access learning centers and learning advisors, but articles that address classroom-based support are also emerging (Dam, 2018; Eto et al., 2020). This article adds to that body of work by offering transparency on practical aspects taken in aiding students in a course-based environment to take charge of their out-of-class learning. The article shares some different ways the authors approached the self-directed learning (SDL) courses that they taught. The courses spanned two semesters with 90 -minute classes held once a week. Course aims were set by the university and there was a common assessment framework specified in the syllabus of all instructors' SDL courses. However, instructors had autonomy in determining lesson content within these boundaries.

The article introduces some key tasks that each author integrated into their individual SDL course, namely: language learning histories, future self exploration, planningaction-reflection cycles, negotiated goal contracts, learning logs, and asynchronous peer interaction. Through sharing research outcomes, experiences and insights, the authors hope to contribute knowledge of ways in which SDL can be approached within coursebased contexts. In the sections below, each of the four authors elaborate upon ways in which they have put learner support into practice.

\section{Language Learning Histories and the Future Self}

In the authors' JALT2020 forum, Louise Ohashi introduced the dual concepts of language learner histories and the L2 future self. Examining their own language learning experiences offers students the opportunity to consider and reflect on how they have learnt over time. Mercer notes that writing language learning histories can benefit learners as it "can help foster their metacognitive awareness both of language learning per se and of themselves as learners" (2013, p. 164). In Louise's SDL classes, she shared some of her language learning history, including positive and negative experiences, with explanations about how she felt at various stages of the journey and some methods that had worked and not worked for her. Students were also provided with a link to a video of someone recounting their language learning history (there are many on YouTube for teachers to choose from) and written versions produced by learners at Chuo University in Japan (Chuo University, n.d.). Students wrote their histories for homework then shared them in small groups in class.

After sharing their language learning histories, students were prompted to consider their futures. In his development of the L2 Motivational Self System, Dörnyei explored the notion of the Ideal L2 Self, which he defines as:

the L2-specific facet of one's 'ideal self': if the person we would like to become speaks an $\mathrm{L} 2$, the 'ideal $\mathrm{L} 2$ self' is a powerful motivator to learn the $\mathrm{L} 2$ because of the desire to reduce the discrepancy between our actual and ideal selves. (2009, p. 29)

After in-class discussions about how identifying goals helps people to achieve them, students were prompted to think about their life in the future and write about their goals and the role their target language(s) played in this. Students were told they could write about one particular time in the future or multiple points in time. They completed the writing task for homework then shared their work in groups in class.

The decision to have students consider their language learning histories before their future selves was made because language learning histories "can serve a vital role in helping learners to envision their futures and set goals based on their current perceptions of themselves and their contextual affordances as well as their interpretation of their pasts" (Mercer, 2013, p. 165). Furthermore, from the point of view of the teacher, including both tasks provided great insight into students' experiences and hopes, highlighting their individual identities and needs. Asking students to share their learning experiences "can convey a respect and genuine interest on the part of the teacher in the learners as individuals, which can thereby enhance the teacher/learner relationship" (Mercer, 2013, p. 164); something that resonated strongly in this author's experience with her SDL students. 
JALT2020 COMMUNITIES OF
TEACHERS \& LEARNERS

\section{Planning-Action-Reflection Cycles}

In the JALT2020 forum, Louise Ohashi also introduced ways in which she led her SDL students through planning-action-reflection cycles. The planning part refers to personal learning plans that focus on each individual's goals. These plans take into account such factors as students' personal learning preferences, capabilities and time commitments. The basic elements of these cycles have been introduced in her earlier work:

- outline long-term and short-term goals,

- identify tasks that will build towards goals,

- list the tasks in a SMART way,

- discuss the plans in class,

- take action outside of class,

- discuss the action (or inaction) in class,

- reflect on the experience,

- modify plans if necessary, and

- continue the cycle.

(Ohashi, 2018, pp. 237-238)

The development of this cycle was initially influenced by the work of Smith (2010), who credits self-planning, self-monitoring, and self-evaluation as integral to learner autonomy. Following the above model, Louise's SDL students outlined their long-term goals after considering their future selves. They wrote them outside of class then shared them with their classmates and teacher during lessons. After this, they worked on study plans of various lengths. For example, in one project students created a four-week plan. To prepare, they consider what they could achieve in four weeks (their short-term goals) that would help them work towards their long-term goals. After that, they considered tasks that could be undertaken to achieve the goals. For example, if they were aiming to improve their listening skills, they identified tasks such as listening to podcasts. During the course many learning tools and methods were shared and students drew from these and others to select appropriate tasks. Listing tasks forms the backbone of a learning plan, but simply making a list is insufficient; tasks need to be SMART.

SMART goal setting, a concept adopted into language education (Anches Holzweber, 2019; McManus \& Kotzé, 2019; Ohashi, 2019) from business settings, was originally outlined as follows:
1. Specific: target a specific area for improvement.

2. Measurable: quantify, or at least suggest, an indicator of progress.

3. Assignable: specify who will do it.

4. Realistic: state what results can realistically be achieved given available resources.

5. Time-related: specify when the result can be achieved.

(Doran, 1981, p. 36)

The acronym has been redefined in slightly different ways over time. In Louise's courses, students were prompted to consider the following keywords and questions when making learning plans:

- Specific: What do you want to work on/do in (each week/part of the project)?

- Measurable: Have you added the number of times you will do tasks, how long you will spend on them, or other ways to measure task achievement?

- Achievable: Can you really complete the tasks? Is it likely? Do you want to do these tasks? Have you considered the balance of tasks that you need to do and those you want to do?

- Relevant: Do your tasks match your goals? How will they help?

- Time-related: When will you do the tasks? Do you have different deadlines for different tasks?

After making their plans, students shared them with their classmates and teacher and made modifications if desired, then began the first week by putting their plans into action outside of class. In the next lesson, they shared their experiences in groups, talking about what they could and could not achieve, and considering the reasons. This provided an important opportunity to receive encouragement, learn from peers, and reflect on their own learning. Then students shared the next week of their plan in groups, decided whether they would like to make any changes or not, and began week two outside of class. Throughout the cycle, the teacher read and/or participated in discussions about plans and outcomes, and offered encouragement and feedback. At the end of the four weeks, students shared their experiences and reflections in presentations, then a new cycle began. When students completed the final SDL class, they submitted a plan for the spring break, with the understanding and hope that they would continue managing their learning themselves, which is the ultimate goal of the SDL courses. 
JALT2020

COMMUNITIES OF
TEACHERS \& LEARNERS

Ohashi, Delgrego, Underwood, \& Abe: Teachers as Self-Directed Learning Guides

\section{Negotiated Goal Contracts}

In any course, proper assessment can be a difficult task. In SDL, the instructor may have more difficulty choosing both a means of evaluation and assigning a fair grade representing the learner's journey. The instructor could assess the quantity or quality of learning. Equally, the instructor could assess the learner's organization and management skills. Noguchi (2014) reminds us that SDL courses have both observable skills and unobservable skills, which can be challenging to assess. There are other factors outside of the instructor's control that influence assessment. These can include departmental/ institutional policies, grading guidelines, and general student concerns. In SDL, perhaps the most important (and simultaneously most difficult) area to assess is whether the learner is aware of their development.

One suggestion to SDL instructors, as introduced by Nicholas Delgrego in the authors JALT2020 forum, would be the use of a negotiated goal contract. A negotiated goal contract is an excellent way for students and teachers to monitor progress and can be used to inform grading. Negotiated goal contracts (also sometimes referred to as grading contracts) are not a new invention, with over a 40-year history in the North American education system (Boud, 1989; Hassencahl, 1979). Currently, these contracts are often widely used in Writing Composition courses (Danielewicz \& Elbow, 2009). They allow writing instructors to holistically score a writer's process as opposed to a single final product. This process over product approach can be directly applied to SDL.

A negotiated goal contract can take many forms. Some instructors prefer them to be online shared documents (Google Docs). Others prefer to use a more traditional format to mimic an actual paper contract. Regardless of structure, a negotiated goal contract must have clearly stated goals (what?) and requirements (how?). In one example, used in Nicholas's course, the following items are included in the contract:

- Date

- Name

- Statement of Goal

Reasoning

- Possible Difficulties

Sub-Goal (Weekly Goal)

- Check Point

- Signature
This is not an extensive list. In SDL courses, a learner can think deeply about these items and, with the instructor's assistance, make an attainable goal with manageable steps. The implementation of negotiated goal contracts allows for more dialogue between instructor and learner and makes the grading process more objective.

After understanding the basics of creating a negotiated goal contract, the next step is to determine how to use it most effectively. What follows is an example of how these contracts can be renegotiated and implemented throughout the semester. Other language courses commonly have a midterm and final test or exam. In contrast, SDL tends not to lend itself to a traditional midterm or final exam and requires needs analysis throughout the course. A negotiated goal contract can be used multiple times over a semester to satisfy students' needs analysis and serve as an alternative to traditional midterm/final term exam assessments.

In the first week of the class, an instructor can introduce and explain the background of negotiated goal contracts. Using SMART goals (described above), learners can begin to think about what they want to achieve over the entire semester. It is recommended that the instructor schedule conference time for the learner to discuss the contract. The instructor can ask the student to explain the reasoning behind their choices and how they plan to accomplish their goals. The instructor can provide advice about goals to the student at this stage but should allow for students to make their own decisions, even if this leads to plans not always being achieved, as students can learn through their own successes and failures. In true contract fashion, an instructor and learner should sign the contract, signifying they are both aware of the learner's goals. By spending time explaining, assigning, and conferencing for negotiated goal contracts, the instructor has created Teacher-time, Learner-time, and Together-time (Dam, 1995, 1999, 2016 as cited in Curry et al., 2017). The combination of these three "times" can provide a stable and encouraging learning environment.

Once the initial negotiated goal contracts have been set, learners will need time to carry out their plans as per their contracts and reflect upon them. By definition, these contracts are negotiated, and key tenets of SDL include the ability to renegotiate and reevaluate one's goals and progress. At the midpoint of the semester, where students would typically be preparing for a midterm exam, an SDL course that uses negotiated goal contracts would be preparing for a second meeting. In his course, Nicholas gives out new, blank contracts for students to fill in and negotiate from the first contract. Questioning is an extremely important tool for the instructor and student at this stage. The instructor should ask questions, such as, "How is your goal progressing?" and "At this stage, do you feel value in your goal?" For some learners, this conference will be a 
mere "checkup" with their original plans going smoothly. For others, reevaluation and negotiation will be necessary. Several learners may have realized their projects were too large or too small. Likewise, some learners may find their SDL plans not as useful as they envisioned when they created them. At this point, the instructor should assist the learner in drafting a revised contract and utilizing this for the course duration.

In the final weeks of the course, the instructor will need to see the learner's work outcome. At this point, the instructor can give a final blank contract for the learner's reflection. The learner should compare their original goal with their final goal and determine how much of their overall goal they could accomplish as per the previous contracts. The instructor should schedule exit interviews and allow learners to present the outcomes of their SDL using the contract as a basepoint.

This was one brief example of how to incorporate negotiated goal contracts into an SDL course. Negotiated goal contracts help the learner to have more control over their learning and align with their interests and motivation. For the instructor, these contracts allow direct communication with learners. They also give instructors a means to assess a very complicated area of assessment. The final assessment is left to the instructor, but as stated earlier, a grading contract helps to clarify the learners' journey, quality and quantity of learning, organization and management skills, and observable and unobservable skills. These are some of the possible criteria that can be assessed in an SDL course. The use of negotiated goal contracts is a clear and concise way to ensure that the learner and the instructor are aware and able to help the learner achieve their plans.

\section{Learning Logs}

In another section of the authors' JALT2020 forum, James Underwood introduced and explained how students in his SDL class effectively used Learning Logs to track their learning and as a basis for their end-of-course self-assessment. These Learning Logs initially took the form of a 40-page notebook, in which the instructor guided the students to write a plan for their self-study each week, record their learning as they did so, and complete reflective tasks. Although these Learning Logs had some similarities to Benson's (2011) "record of work form" that his University of Hong Kong students used there were some differences. Like Benson's (2011) form, James's students wrote a plan for their self-study each week, then recorded their learning as they did so, but instead of reflecting on how their work related to the achievement of their future goals in written form each week, they did this verbally. Another difference was that they created a detailed "Ideal Self" vision (Dörnyei, 2009) as an initial task in the creation of their learning log, which they would refer back to throughout the course.
In this task, they were asked to imagine themselves as successful English users in their studies, careers, or social lives, and write at least a paragraph that detailed how they felt, why English was essential for them, and what they did with English. Following this, they then thought about what skills they needed to achieve this vision, much like Dörnyei's (2009) "Ought-to Self". When they did so, the instructor advised them to break down their vision into SMART goals similar to those described above. The instructor also recommended that they focus their weekly self-study on developing one of the four skills throughout the semester. To supplement their self-study, the instructor concentrated on a particular skill each week and introduced resources and activities that they could use to develop this skill extensively and intensively. The students were then expected to improve their chosen skill through 90 minutes of self-study each week and record their learning in their notebooks. In response to the move to online classes that happened due to the COVID-19 pandemic, a Google Doc replaced this notebook system. In the forum at JALT2020, James outlined how this Google Doc was designed and used in the classroom.

When designing the Google Doc that students would use as their Learning Log, James created one document, which the students would use as a template and share with him. This document had four main sections:

- An Introduction and Overview

- What is a SMART plan?

- What kind of records?

- The Weekly Record section

The "Introduction and Overview" contained a reminder of the course requirements: 90 minutes of self-study a week which they should record accurately using the Learning Log. Before this self-study, they were expected to make a SMART plan each week and then work towards this. The "What is a SMART plan?" section explained what SMART goals were and gave examples. The "What kind of records?" section contained various record-keeping examples for each of the four skills. Although there was some flexibility in how the learners recorded their learning, the instructor hoped that this section would raise awareness of the detail required. The "Weekly Record section" was where the learners first made a SMART plan for the week and recorded their work.

When using the Learning Logs, the students would first make a SMART goal for the week, and then during the week, they would document what they did to realise this. The way they did so varied according to the resources they were using. If they used language learning applications such as Xreading, they would often take screenshots of 
the summary screen, including information about the time spent and their score in the reading quiz. If they watched presentations on TED Talks in English, they would either take notes while listening or write a summary after listening that detailed the materials used, how they were used, and what they learned from them. If the students read a news article, they would then take notes that would also include a summary of the article written in their own words and a word list. Most students preferred to take these notes by hand and take a photo of them, which they would then upload to their Learning Log. The variety with which they recorded their learning illustrated one of the advantages of using Google Docs, which allowed them to combine screenshots of online work with photos of their handwritten work much more conveniently than before. Previously, if students used online applications in the old notebook system, they would have to take screenshots, then print them out, cut them to size and glue them to their notebooks.

At the start of each lesson, as a warm-up activity, the students worked in small groups of three or four and shared what they did for their self-study using these focus questions:

- What did you plan to do?

- What did you do as part of your self-study learning?

How successful were you?

- Are you going to do anything differently next week? If so, what?

Kato and Mynard, maintain that an integral part of "structured awareness-raising" is "reflecting on previous learning, sharing experiences with others, considering alternatives, being exposed to different ways of learning, and trialing and appropriating forms of learning that work best for an individual or situation" (2016, Structured Awareness Raising section, para. 1). Thus, the instructor hoped that this activity would be beneficial in the way described.

Overall, in the instructor's view, using Google Docs was a successful way to track learning while teaching online. The students found them convenient to use, and the instructor could easily view their work and give them advice if needed. The students could also use them as a basis for discussing and sharing their learning with each other each week. James will continue to use this system after moving back into the classroom and other teachers may also find this to be a useful method in tracking their students' learning.

\section{Asynchronous Peer Interaction}

Although SDL is a type of learning directed by individual learners, it does not mean that they should learn alone. Considering the nature of a language as a communication tool, learners need abundant opportunities for communication in the target language. Besides, many studies have suggested that peer interaction promotes learning (e.g. Boud et al., 2013; Crouch \& Mazur, 2001; Philp et al., 2014; Topping, 2005), which naturally leads to positive impact of interactive activities on SDL. Thanks to advancement of technologies, it is very easy today even for self-directed learners to interact with other learners using online tools.

To find out more about this practice and contribute knowledge through research at JALT2020, Mayumi Abe explored the use of asynchronous peer interaction with her students and investigated its effects, especially with higher-order thinking skills, on SDL. She named the activity HOTS \& Sharing (HOTS = higher order thinking skills), the idea for which came from the 4Cs framework of CLIL consisting of Content, Communication, Cognition and Community (or Culture) (Watanabe et al., 2011). Among these $4 \mathrm{Cs}$, Content and Communication could be easily applied to SDL, such as in extensive reading in which learners enjoy the content of reading materials (Content) written in the target language (Communication). On the contrary, Cognition and Community might be challenging to apply for self-directed learners without support or scaffolding. The HOTS \& Sharing activities Mayumi integrated into her course aimed to facilitate Cognition (HOTS) and Community (Sharing) in self-directed extensive reading.

The students were guided to begin extensive reading in April and continued it to July 2019. Although extensive reading as well as vocabulary building were required activities in the course, decisions regarding materials and amount and frequency of reading were entrusted to students because the course aimed to nurture such self-management learning strategies. The period of extensive reading was for six weeks in total and divided into 3 phases with 2 weeks each. In Phase 1 , students started to keep a Reading Log without interactive activity. In Phase 2, students kept a Reading Log and also were encouraged to write summaries of books they read, upload them in an online forum, and write comments to their classmates' postings. In Phase 3, they continued to keep a Reading Log, and for the online forum, they wrote book reviews instead of summaries by answering two questions presented by the teacher and comments to others' reviews. The two questions were "What was interesting/surprising for you? Why?" and "What can be connected/applied to your life? How?" Answering these questions is assumed to require higher-order thinking skills more than writing summaries. From the view of the $4 \mathrm{Cs}$ 
framework, Phase 1 included Content and Communication. In Phase 2 Community was added as interactive commenting and in Phase 3 Cognition as review writing.

The students were provided with a digital format of the Reading Log made with Word so that they were able to keep it on their computer and submit it via the course's LMS (Moodle). In the Reading Log, they reported titles, publishers/authors, genres, dates, and numbers of pages and words of their reading. A forum was set in Moodle for asynchronous interaction in Phase 2 and 3, where the students were guided to pos summaries or reviews about books they read and write comments to their peers' posts While the Reading Log was a requirement, posting in the forum was voluntary and not used for grading, which was clearly explained to the students in advance. Additionally, the students answered a questionnaire after the whole period of extensive reading. It asked their interest and preference for extensive reading at two points, before and after the extensive reading activities in the course, with a five-point rating scale. For the study below, permission was obtained from the university in advance. Besides, the students were provided oral and written explanations not only about the activities but also about the study and agreed to participate with a written document.

The results of the study were as follows. First, the average number of words the students read in each phase from Phase 1 to Phase 3 was compared (Phase 1, 37,348; Phase 2

33,937; Phase 3, 43,204). Results showed the number was the highest in Phase 3 but slightly decreased from Phase 1 to 2 . Therefore, it remains uncertain whether the interaction encouraged the students to read more. Second, the total number of comments posted in Phase 2 and 3 was compared. Results showed the average number of comments was 1.7 in Phase 2 and 2.8 in Phase 3, which indicates that the students engaged in interaction more actively with reviews than summaries. It could be assumed that interaction with higherorder thinking skills might promote communication among self-directed learners. Third, responses from the questionnaire regarding interest and preference for extensive reading were compared before and after the activities. Greater agreement was identified for interest (average of 3.5 before, 3.7 after) and preference (average of 3.4 before, 3.7 after) after the activities, which revealed the students were more interested in and liked extensive reading better after the activities. Although the part of the process that was the most effective cannot be clearly identified at this time, it could be said that the experiences as a whole including HOTS \& Sharing had a positive impact on the students.

In light of these results, it might be worth considering the importance of teachers, as educators and guides for self-directed learners, providing learners with opportunities for interaction, especially communication that involves higher-order thinking skills. Not only teaching learners what to learn and how to learn it, but also facilitating their learning environment by including interactions with others, could be an important role of teachers in promoting self-directed learning.

\section{Conclusion}

This article has shared practical ways in which the four authors supported their students in year-long SDL courses, outlined key theories that were drawn on in determining how to offer support, and contributed research findings. In Japan, it is still uncommon for SDL to be taught as a required, stand-alone, credit-bearing subject, but institutions may like to consider the benefits of offering this type of support to their students. When setting up such courses, the contributions made by these four authors may prove valuable. Furthermore, teachers of language courses could adopt or adapt some of the support methods to suit their own teaching contexts. There is a need for greater transparency in how SDL is practically addressed in classrooms, so the authors hope this article not only assists others in understanding ways in which it is already being done, but also encourages other educators to add to this body of work.

\section{Bio Data}

Louise Ohashi is a professor at Meiji University who specializes in English language education. Her doctoral work and much of her other research examines teacher support of learner autonomy, learner motivation, and the use of digital technologies for language learning. Along with her passion for teaching English, she is an avid language learner who speaks Japanese, French, and Italian. Follow her on Twitter @OhashiLou for updates on her work. <ohashijalt@gmail.com>

Nicholas Delgrego is a full-time lecturer at Tsuru Bunka University with a background in English language education. Over the course of the past 15 years, he has taught at the primary, secondary, and tertiary level within Japan. He is currently pursuing his doctorate investigating the impact of writing centers and peer learning at Japanese universities. He is also a committee member of the Writing Center Association of Japan. <delgrego@tsuru.ac.jp>

James Underwood has taught part-time at Gakushuin University, and several other universities in the Tokyo and Chiba area, since 2016. He has a Masters in Applied Linguistics and TESOL, and his research interests include learner development and autonomy. He is a committee member of the JALT Learner Development SIG, and helps to organize the Tokyo get-togethers, and the Creating Community Learning Together conferences that are connected to these. <jamesmichaelunderwood@gmail.com> 
Mayumi Abe is an assistant professor at the Center for Higher Education Studies of Waseda University. She received her master's degree in TESOL from Temple University and doctor's degree in Human Sciences from Waseda University. Her research interests include instructional design, learning design, and professional and learner development. She is currently exploring the possibility of applying learning analytics to learning design for self-directed learners. <mayumiabe@fuji.waseda.jp>

\section{References}

Anches Holzweber, M. A. (2019). Self-directed-learning and e-learning as triggers for higher student motivation in EFL courses in tertiary education. Journal of Applied Languages and Linguistics, 3(3), 68-79.

Benson, P. (2011). Teaching and researching autonomy (2nd ed.). Pearson Education Limited. Blidi, S. (2017). Collaborative learner autonomy. Springer.

Boud, D. (1989). The role of self-assessment in student grading. Assessment in higher education, 14(1), 20-30.

Boud, D., Cohen, R., \& Sampson, J. (Eds.). (2013). Peer learning in higher education. Routledge.

Chuo University. (n.d.). Examples of students' work: Language learning histories. http://c-faculty. chuo-u.ac.jp/ mikenix1/tlr/work/llh/

Crouch, C. H., \& Mazur, E. (2001). Peer instruction: Ten years of experience and results. American Journal of Physics, 69(9), 970-977. https://doi.org/10.1119/1.1374249

Curry, N., Mynard, J., Noguchi, J., \& Watkins, S. (2017). Evaluating a self-directed language learning course in a Japanese university. International Journal of Self-Directed Learning, 14(1), 37-57.

Dam, L. (2018). Learners as researchers of their own language learning: Examples from an autonomy classroom. Studies in Self-Access Learning Journal, 9(3), 262-279. https://doi. org/10.37237/090303

Danielewicz, J., \& Elbow, P. (2009). A unilateral grading contract to improve learning and teaching. College Composition and Communication, 61(2), 244-268.

Doran, G. (1981). There's a S.M.A.R.T. way to write managements' goals and objectives. Management Review, 70, 35-36.

Dörnyei, Z. (2009). The L2 motivational self system. In Z. Dörnyei \& E. Ushioda (Eds.), Motivation, language identity and the L2 self (pp. 9-42). Multilingual Matters.

Eto, T., Saunders, M., \& Itoi, K. (2020). Classroom-based training towards learner autonomy. JASAL Journal, 1(1), 37-61.

Hassencahl, F. (1979). Contract grading in the classroom. Improving College and University Teaching, 27(1), 30-33.
Holec, H. (1981). Autonomy and foreign language learning. Pergamon.

Kato, S., \& Mynard, J. (2016). Reflecting dialogue: Advising in language learning. Routledge. https:// doi.org/10.4324/9781315739649

Lai, C. (2017). Autonomous language learning with technology: Beyond the classroom. Bloomsbury. Little, D. (1991). Learner autonomy 1: Definitions, issues and problems. Authentik.

McManus, C. \& Kotzé, H. (2019). Mission: ENGAGE! Gamifying goals to launch student engagement beyond the classroom. English Australia Journal, 35(1), 53-58.

Mercer, S. (2013). Working with language learner histories from three perspectives: Teachers, learners and researchers. Studies in Second Language Learning and Teaching, 3(2), 161-185. https://doi.org/10.14746/ssllt.2013.3.2.2

Murphey, T., \& Jacobs, G. M. (2000). Encouraging critical collaborative autonomy. JALT Journal, 22, 228-244. https://doi.org/10.37546/JALTJJ22.2-1

Murray, G. (2014). Autonomy in language learning as a social construct. In G. Murray (Ed.), Social dimensions of autonomy in language learning (pp. 233-249). Palgrave Macmillan.

Noguchi, J. (2014). Evaluating self-directed learning skills in SALC modules. Studies in Self-Access Learning Journal, 5(2), 153-172.

Ohashi, L. (2018). Self-directed learning and the teacher's role: Insights from two different teaching contexts. In P. Taalas, J. Jalkanen, L. Bradley \& S. Thouësny (Eds), Future-Proof CALL: Language Learning as Exploration and Encounters: Short Papers from EUROCALL 2018 (pp. 236-242). Research-publishing.net. https://doi.org/10.14705/rpnet.2018.26.843

Ohashi, L. (2019). Using digital technology for autonomous, out-of-class English language learning: The influence of teacher support at a Japanese university (Doctoral dissertation, Charles Sturt University, Australia). Retrieved from https://researchoutput.csu.edu.au/en/publications/usingdigital-technology-for-autonomous-out-of-class-english-lang

Philp, J., Adams, R., \& Iwashita, N. (2014). Peer interaction and second language learning. Routledge. Smith, K. (2010). In pursuit of learner autonomy: Strategy-based instruction, a key approach for Japanese students. Meisei University Humanities Review, 46, 117- 135.

Topping, K. J. (2005) Trends in peer learning. Educational Psychology, 25(6), 631-645. https://doi org/10.1080/01443410500345172

Watanabe, Y., Ikeda, M., \& Izumi, S. (2011). CLIL (内容言語統合型学習)一上智大学外国語教育の新 たなる挑戦第1巻:原理と方法 [CLIL (Content and Language Integrated Learning): New challenges in foreign language education at Sophia University. Vol.1: Principles and methodologies]. Sophia University Press. 